\title{
Activities of Daily Living of Aged In-patients
}

\author{
by \\ Masuji Seki and Satoshi Ueda \\ from \\ Yokufukai Geriatric Hospital, Tokyo
}

ABSTRACT

Activities of daily living (ADL) of the aged in-patients of Yokufukai Geriatric Hospital were surveyed. The level of independence in ambulation, self-feeding, dressing, bathing and toilet activities, as well as the spatial range of ambulation or living were determined for each patient. An ADL index was then calculated from the results; full independence in each of the items being awarded 2 points, semidependence 1 point, and full dependence a 0 . The index thus ranges from a 0 of total dependence to a 12 "of full independence. Of the 235 patients, 67 were males and 168 were females. Two were in the sixth decade, 40 to the seventh, 108 to the eighth, and 86 were over eighty. The majority were chronic cases, and about $70 \%$ had stayed in the hospital more than a year.

The results of the survey were:

1) Independent ambulation without support was possible in $40 \%$ of the subjects, ambulation with a cane in $15 \%$ and confinement in wheelchairs and/or beds was seen in $43 \%$ of the cases. The spatial range of ambulation or living was generally restricted, about $85 \%$ being unable to go beyond their own wards. In self-feeding, 76\% could use chopsticks and $6.4 \%$ were fully dependent. About $62 \%$ needed assistance in dressing. Assistance in bathing was required in $75 \%$ of the subjects. Fortyfive per-cent of the subjects could go to the toilet, $24 \%$ used bedside commodes and $31 \%$ were kept with diapers.

2) The mean score of the ADL index was 5.7. The total cases could be devided into three groups according to their grades ; $34 \%$ belonged to mild impairment in ADL (score $8-11$ ), 26\% to moderate impairment $(3-7)$ and $33 \%$ to severe impairment (0-3).

3) A progressive decline in index score was seen to occur with age.

4) Those patients with cerebrovascular accidents exhibited lower score than patients of suffering from other non-cerebrovascular disease. 


\section{老年者入院患者の日常生活動作能力}

関増 爾* 上田敏**

\section{I. 目 的}

さきと，養護老人ホームと和けるいわゆる健康老年者 の日常生活動作能力（A D L) を調查し, 老年者では 1 年間という短期間飞括いても能力の低下があることを認

表 1 対象人員

\begin{tabular}{c|r|r|r}
\hline 年 齿会 & 男(\%) & \multicolumn{1}{|c|}{ 女(\%) } & \multicolumn{1}{|c}{ 計(\%) } \\
\hline ５9 & & $2(1.2)$ & $2(0.9)$ \\
$60 \sim 64$ & $7(10.4)$ & $4(2.4)$ & $11(4.7)$ \\
$65 \sim 69$ & $11(16.4)$ & $17(10.1)$ & $28(11.9)$ \\
$70 \sim 74$ & $15(22.4)$ & $32(19.1)$ & $47(20.0)$ \\
$75 \sim 79$ & $18(26.9)$ & $43(25.6)$ & $61(26.0)$ \\
$80 \sim 84$ & $8(11.9)$ & $36(21.4)$ & $44(18.7)$ \\
$85 \sim 89$ & $6(8.9)$ & $27(16.1)$ & $33(14.1)$ \\
$90 \sim$ & $2(2.9)$ & $7(4.2)$ & $9(3.8)$ \\
\hline 計 & 67 & 168 & 235
\end{tabular}

表 2 入院前所属（全 235 名）

\begin{tabular}{c|c}
\hline 浴風園養護老人ホーム & \\
一 般 寮 & 110 名 \\
虚 弱 寮 & 60 \\
新入 者寮 & 25 \\
有料老人ホーム & 3 \\
直 接入院 & 37
\end{tabular}

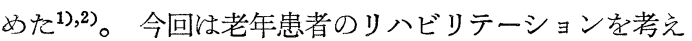
るための基礎資料を得る目的で，老年者入院患者の A D しを調査した。

\section{II. 調 查対象}

対象は昭和 42 年 3 月, 浴風園病院の一般病棟に入院中 の主として60歳以上の老年患者 235 名で, 男子67名, 女 子 168 名である。年齢分布は表 1 のごとく, 70 歳代が約 半数を占め, 次いで80歳代, 60 歳代の順である。

* 浴風会・浴風園病院

**浴風会・浴風園病院, 東大中尾内科
入院患者の入院前所属は表 2 のごとく, 浴風園養護老 人ホームの一般寮, 虚弱寮怙よび新入者観察寮加 195 名で，大部分を占める。

入院患者の調查日までの入院期間は表 3 のごとく， 年以上が約 $70 \%$ を占め, 慢性病患者が多い。そして入院

表 3 入院期間（全 235 名）

\begin{tabular}{|c|c|c|c|c|}
\hline 期. 間 & 実 & 数 $(\%)$ & 期 間 & 実 数 $(\%)$ \\
\hline$\sim 1$ 力月 & 14 & & $4 \sim 5$ 年 & $19(8.1)$ \\
\hline $1 \sim 3$ & 12 & & $5 \sim 6$ & $12(5.1)$ \\
\hline $3 \sim 6$ & 18 & $72(30.7)$ & $6 \sim 7$ & $5(2.1)$ \\
\hline 6 月〜 1 年 & 28 & & $7 \sim 8$ & $8(3.4)$ \\
\hline $1 \sim 2$ & & $51(21.7)$ & $8 \sim 9$ & $4(1.7)$ \\
\hline $2 \sim 3$ & & $38(16.2)$ & $9 \sim 10$ & $3(1.3)$ \\
\hline $3 \sim 4$ & & $17(7.2)$ & $10 \sim$ & $6(2.6)$ \\
\hline
\end{tabular}

表 4 入院患者病名 (全 235 名)

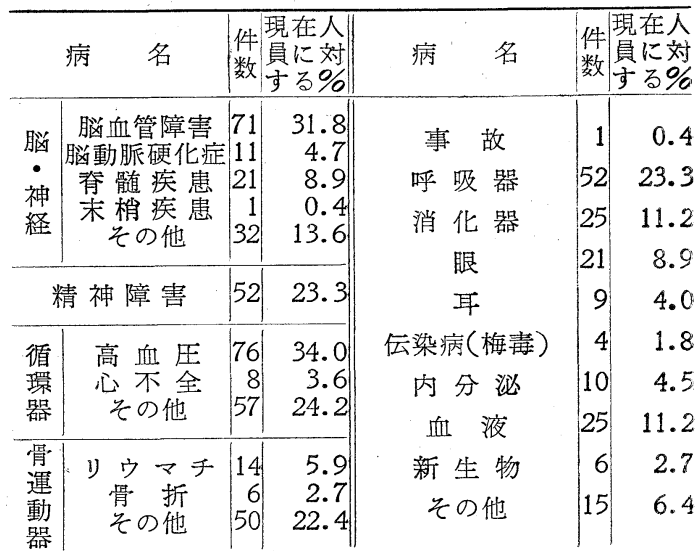

注：\%の計が 100 以上となるのは，1 人で 2 種以上 の病名を有する者があるからである。

患者の疾患は表 4 のごとく, 循環器疾患あるいは脳・神 経系疾患を有する者が約半数あり，次いで骨和よび運動 器疾患, 呼吸器疾患などである。

\section{III. 調查方法}

AD L 調査は病室看護婦の観察に基づいて行なった。 
表 5 A D L 調査項目および評価方法

\begin{tabular}{|c|c|c|c|}
\hline 項目 評価点 & 0 点 & 1 点 & 2 点 \\
\hline 1. 歩 行 & 介助・車椅子 & 杖・つかまり & 自立步行 \\
\hline 2. 歩行範囲 & 居室内・なし & 建物内 & 敷 地 内 \\
\hline 3. 食 事 & 介 助 & サ $シ ゙$ & 八: シ \\
\hline 4. 着 衣 & 全 介 助 & 部 分介助 & 自分でする \\
\hline 5. 入 浴 & 清 拭 & 介 助 & 自分でする \\
\hline (5.)用 便 & おむつ & 便 器 & 便所へ行く \\
\hline
\end{tabular}

表 6 ADL各項目別 (全235 名)

\begin{tabular}{|c|c|c|c|c|c|c|c|}
\hline & 項 目 & 夷数 & $\%$ & & 項 目 & 実数 & $\%$ \\
\hline & $\begin{array}{c}\text { 自立歩 行 } \\
\text { 杖 } \\
\text { 介助・車椅子 } \\
\text { 不 能 }\end{array}$ & $\begin{array}{l}99 \\
36 \\
22 \\
78\end{array}$ & $\begin{array}{r}42.1 \\
15.3 \\
9.4 \\
33.2\end{array}$ & 着 & $\begin{array}{l}\text { 自分でする } \\
\text { 半介助 } \\
\text { 全介助 }\end{array}$ & $\begin{array}{l}88 \\
58 \\
89\end{array}$ & $\begin{array}{l}37.5 \\
24.7 \\
37.9\end{array}$ \\
\hline & $\begin{array}{l}\text { 敷 地内 } \\
\text { 建物内 } \\
\text { 室 内 } \\
\text { な }\end{array}$ & $\begin{array}{r}25 \\
13 \\
118 \\
79\end{array}$ & $\begin{array}{r}10.6 \\
5.5 \\
50.2 \\
33.6\end{array}$ & 入 & $\begin{array}{c}\text { 自分でする } \\
\text { 介 助 } \\
\text { 全介助(清拭) }\end{array}$ & 58 & $\begin{array}{l}24.7 \\
36.4 \\
38.8\end{array}$ \\
\hline & $\begin{array}{l}\text { シ } \\
\text { サ } \\
\text { 介 助 }\end{array}$ & $\begin{array}{r}42 \\
15\end{array}$ & $\begin{array}{r}75.6 \\
17.9 \\
6.4\end{array}$ & & $\begin{array}{c}\text { 便所へ行く } \\
\text { 便器使用 } \\
お \text { おつ }\end{array}$ & $\begin{array}{l}5 \\
7\end{array}$ & 31.1 \\
\hline
\end{tabular}

調查項目は, 歩行方法, 歩行範囲, 食事方法, 着衣, 入浴, 用 便の6項を選んでとの程度を記載した。また, 表5のよ ラに, 各項目を可能の程度により $0 \sim 2$ 点, 合計 $0 \sim 12$ 点の点数評価を行ない, 各個人のADL点を算出した。

\section{IV. 調査結果の概要}

\section{1. 項目別 ADL の状況}

項目別A D L 状況は表 6 のごとくである。

a ）歩行方法は, 自立歩行可能は約 $42 \%$ マすきず，半 数以上は何らかの補助を要し, 歩行不能者が約 $1 / 3$ あり, これと介助歩行, 車椅子歩行を合せると $42.6 \%$ と達する。

b ）歩行範囲はしたがってきわめて狭く，せいぜい室 内までが83.3\%を占めている。

c）食事はハシ使用者が多いが，介助を要する者が . 5 . $\%$ である。

d）着衣は独立可能者は $37.5 \%$ 囚すぎず，自分ではま ったくできない者が, 37.9\%ある。

e）入浴は自分でできる者が約 $1 / 4$ 亿すぎず， $3 / 4$ は部分 介助, あるい恃全介助または清拭のみである。

f）用便は便所へ行ける者が44.7\%、すぎず，扣むつ 使用者が約 $1 / 3$ を占めている。

以上のように入院患者のADLは非常に低下している。

\section{2. $\mathrm{ADL}$ 点数}

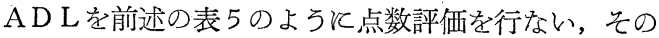
分布を調べた。

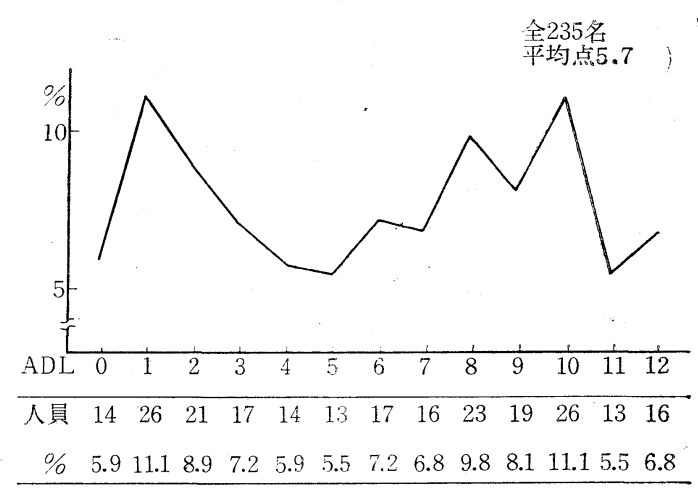

図１大院患者ADL点分布

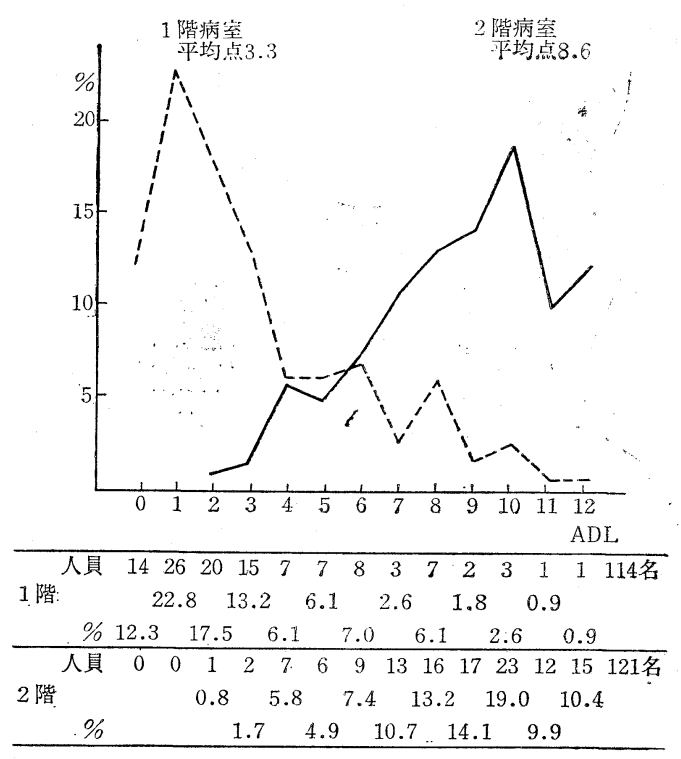

図 2 病室・階別ADL点分布

a）全患者のADL分布蚁 1 のごとくで，1点を中 心とした低点部の山と 8 ～10点を中心とした高点部の山

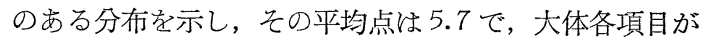
1 点であった場合より, やや低いこととなる。すなわち 平均的な入院患者は, 杖あるいはつかまり歩きで, その 歩行範囲注, せいぜい居室内か屋内であり, 食事はサジ を使い, 着衣叔よび入浴は介助をしてもらって行ない, 用便は便器を使っているということになるう。しかし， 実際にはADL点数の分布からわかるように, そのよう な平均的な患者はもしろ少なく，それよりはADL点数 の低い患者と，高い患者とのほうが多いのである。

b）収容区分とAD L点：浴風園病院は 2 階建であり 看護上，その他の理由から，看護に手のかかる患者に一 階病室に収容している。

今, 1 階と 2 階病室の患者のADL点を比較すると図 

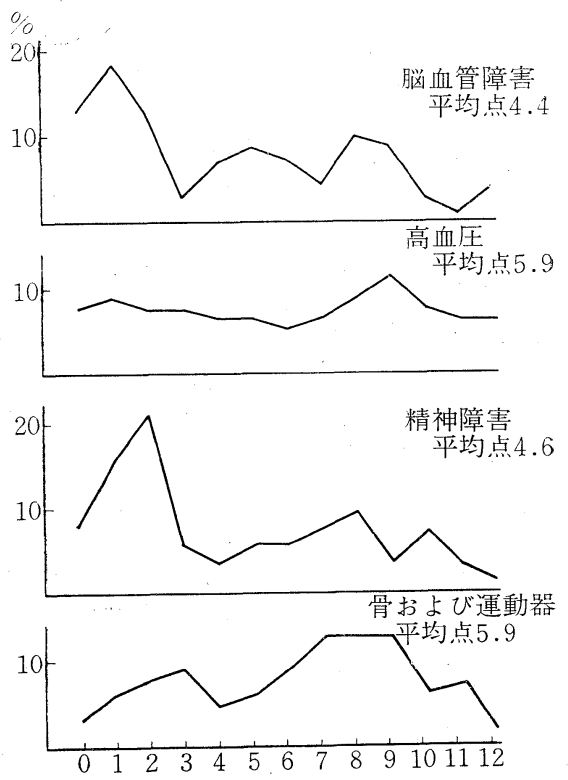

図 3 疾病とADL点

2 のごとく，1階病室は低点部が非常に多く，2階病室 は高点部が多く, その分布曲線はほぼ詨称的であり, そ の差が明瞭で, 平均点は 1 階病室 3.3 点, 2 階病室 8.6 点であった。

c) 疾病之ADL点: 入院患者の有する疾病は表 4 V 揭げたが，これらの中の主要疾病とADL点との関係を 調べた。しかし，入院患者の多くは同時にいくつかの疾 病を有して和り, それらが重なり合った結果, 患者のA DLが制限されてくるので，1人の患者につき 1 つの疾 病のみを取りあげることは当をえないと考えられる。た とえば，脳血管障害者（脳出血, 脳軟化, 脳膜出血など） 71名中脳血管障害のみの患者はわずか13名にすぎず，58 名は他の疾患も有して和り, また, 精神障害52名中精神 障害のみの者はわずかに 5 名にすぎないなどである。し たがって, 純粋にある疾病のみのADLを検討すること は困難であるので，ここでは，ある疾病を有する患者の ADLという意味で検討した。図 3 のごとく，脳血管障 害を有する者, 精神障害を有する者は低点部に山があり AD L平均点はとれぞれ 4.4 和よび 4.6 点と低い。高血 圧, 骨扔よび運動器疾患を有する者の分布曲線は比較的 平坦である。精神障害を有する者のAD L点が低いのは その中の約半数は脳血管障害を合併し, あるいはまた, 循環器疾患も合併して和り, 純粋飞精神障害のみのAD しを示していないと思われる。

非常飞少数例であるが, 精神障害のみの 5 例のA D L 点はすべて 6 点以上で, その平均点が 9.0 点であったこ

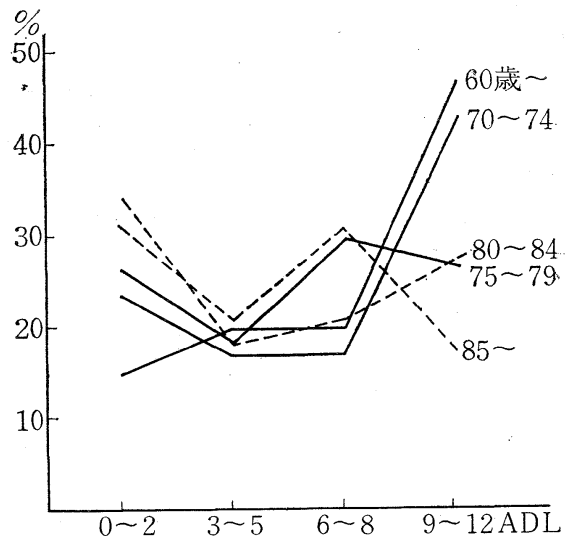

\begin{tabular}{c|ccccc}
\hline 年 踭 & $60 \sim$ & $70 \sim$ & $75 \sim$ & $80 \sim$ & $85 \sim$ \\
\hline 例 数 & 39 & 47 & 61 & 44 & 42 \\
\hline A D L 平均点 & 7.5 & 6.5 & 5.9 & 5.2 & 4.8
\end{tabular}

図 4 年齢とADL点分布

表 7 脳血管性障害を有する例の年齡とADL点

\begin{tabular}{c|c|c}
\hline 年 齢 & 例 数 & A D L 平均点 \\
\hline $60 \sim 69$ & 20 & 5.9 \\
$70 \sim 79$ & 37 & 4.1 \\
$80 \sim$ & 14 & 3.5
\end{tabular}

とからもとれは了解しうると思う。また, 脳血管障害例 のAD L点が低いのは常識的にも考えられるが, 脳血管 障害のみの13例のA D L 平均点が 4.1 点であったこと は，それをある程度立証するに足るであるう。

d）年齢とADL点 : 年齢は対象人員の関係から70歳 以上は5歳区分とした。ADL点の分布は図4のごとく であり， 0〜2 点の者が加龄とともに多くなり， 9 12 点は加齢とともに減少する傾向を示し, その平均点は60 歳代の 7.5 点から加齢とともに低下し, 85 歳以上では 4.8 点となる。さらに脳血管障害を有する例々ついて年 齢とADL点との関係をみると, 表 7 ように, その平 均点は加齢とともに低下した。

\section{V. 総 括}

昭和 42 年 3 月, 浴風園病院の一般病棟に入院中の老年 患者 235 名について, 歩行方法, 歩行範囲, 食事方法, 着衣, 入浴, 用便の6項目を選びADLを調査した。

A D L 項目別には独立歩行不能者は約半数に近く, 歩 行範囲はせいぜい室内までの者が多い。食事はハシを用 ろる者が多いが着衣は約60\%は介助を要し, 入浴は約 $3 / 4$. 


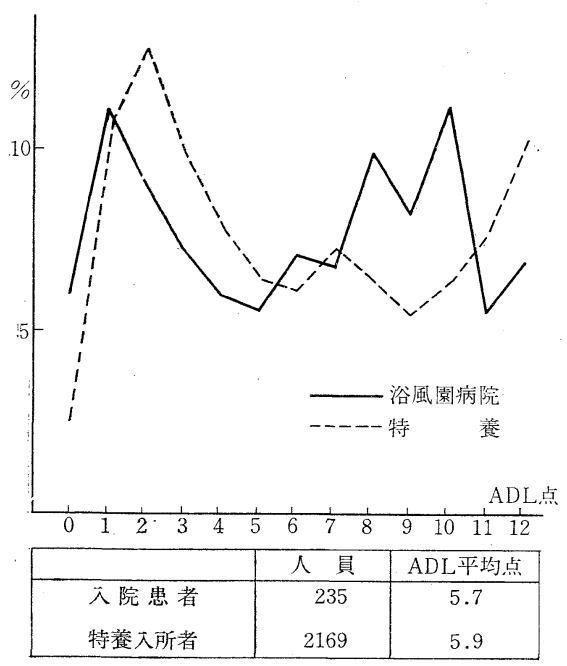

図 5 入院患者之特養入所者のADL点比較

が介助を要する。そして，用便は約 $1 / 4$ が便器を使用し， 約 $1 / 3$ が扮むつを使用している。

A D L 各項目を $0 \sim 2$ 点の点数評価し， 6 項目合計 0 〜12点の13段階飞分けると, 入院患者のA D L 点の平均 は5.7 点であったが，その分布曲線は低点部杼よび高点 部に山があり，中間部は比較的少なかった。

そして, $\mathrm{ADL}$ 点 $8 \sim 11$ 点を $\mathrm{ADL}$ 軽度低下, $3 \sim 7$ 点（大体 6 項目飞ついて半介助あるいはとれ以上の介助 を要する者）を中等度低下，0３点（大体6 項目とも 全介助か，3 項目のみ半介助）を高度低下とすると，12 点（6項目独立可能）の者は $7 \%$ 亿すぎず, 軽度低下者 $34.3 \%$, 中等度低下者 $25.5 \%$, 高度低下者 $33.2 \%$ となり, 中等度以上の低下者が約 $60 \%$ を占めて频り, 老年者入院 患者のA D L は相当飞低下している。一方, わが国の一般 病院入院患者の A D L rついては厚生省, 永川の報告3) があり，その調查方法拉よびA D L 判定基準はわれわれ の方法と異なっているので, 直ちとは比較できないが掠

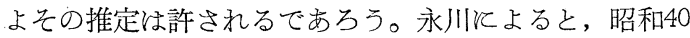

年 3 月の 全国の 無作為抽出病院の入院患者約 17,000 人 中, 非常江手のかかる介助を要する者 (重度) $10 \%$, 中 等度の介助を要する者 $18.7 \%$ に対し, 軽度 $71.3 \%$ であり 浴風園病院に比べ, 軽度低下が多く, 非常に手のかかる 者が少ない。

以上のごとく老年者入院患者のA D L ふわが国一般病 院入院患者のそれて比べ相当低下しているが,これを,最 近，同一項目，同一評価方法を用いて調査しえたわが国 の特別養護老人ホーム (特養) 入所者 2,169 名について の結果 ${ }^{4)}$ と比較すると，図5 のごとくである。両者の $\mathrm{A}$ D L 点分布曲線は, 高点部和任る山が，入院患者では

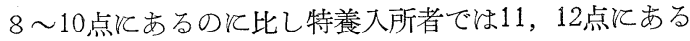
という違いふあるが，低点部に大きな山があり，中間点 が少ないという点でよく類似している。また，ADL平 均点以入院患者 5.7 点飞対し, 特養入所者 5.9 点でその 差はきわめて少ない。すなわち，本調査による6 項目か ら観察した入院患者と特養入所者のA D L は大体同じで あると考兄られ，また，特盖入所者の疾病も入院患者の それとはなはだしく異なってはいない。このことは，特 別養護老人ホームのあり方を考光る上で, 重要な問題で ある弓。

浴風園病院長尼子富士郎博士, 東大医学部中尾喜久教 授のご校閲を深謝する。(本稿の要旨は昭和 42 年 5 月, 第 4 回日本リハビリテーション医学会総会にて発表し た）な㧍，本研究は昭和 41 年度厚生科学研究費の援助 をうけた。

\section{文献}

1 ) 関 増爾: 老人の活動能力, 浴風園調查研究紀 要, $41: 91,1965$.

2) 関 増爾, 他 : 老年者活動能力の 1 年後の変化, 浴風園調查研究紀要, $42: 69,1965$.

3 ) 永川省一: 入院患者の日常生活能力調查の結果 酒つて，厚生の指標，13:19，1966.

4) 関 増爾, 他：特別養護老人ホーム入居者の日 常生活動作能力反関する全国調查成績, 第 4 回 日本リハビリテーション医学会総会, 1967.

$$
O=ュ ー ス
$$

\section{第 8 回 日本巟童精神医学会総会 10月開催}

第 8 回日本览童精神医学総会 月 $7 \cdot 8$ 日の両日飞わたり仙台市の 東北大川内記念講堂で開催される。 会長以東北大教授 和田豊治氏。

総会ではシンポジウムに(1)「児童 精神医学《和ける心理テストの効用 と限界」を慶大助教授 牧田清志氏
(2)「てえかん児童一とくに精神症状 性格, 行動ならびそ社会的諸問題飞 ついて」を国立国府台病院副院長 中川四郎氏の司会でそれぞれ討論す ることとなっている。

また，会長特別講演として「てえ かえ児の精神医学的諸問題の 2 ,
3」をテーマに東北大教授 和田豊 治氏の講演が予定されている。

な和，演題発表の申込みは学会準 備委員会へ 7 月 31 日まで連絡の 上，8月15日末で视 800 字以内の抄 録原稿をそえて東北大医学部精神医 学教室宛送付すること。 